\title{
ODLUKE ZADARSKIH DIJECEZANSKIH SINODA O PRIDRŽANIM SLUČAJEVIMA (DE CASIBUS RESERVATIS) U KONKTESTU KONCILSKE MISLI
}

Zvjezdan STRIKA

Augsburg, Njemačka
UDK: 2-73(497.5 Zadar)

DOI: $10.21857 /$ moxpjhwjqm

Prethodno priopćenje

Prihvaćeno: 26. ožujka 2020.

Reservatio casuum predstavlja dio pokorničke prakse koji se razvio tijekom srednjeg vijeka. Pojedini slučajevi savjesti najprije su bili rezervirani papi, a kada se, uslijed mnogobrojnih problema, takva praksa pokazala neprimjernom, prelazila je polagano na mjesne ordinarije. Oni su preko pokrajinskih sabora i dijecezanskih sinoda određivali koji slučajevi savjesti su rezervirani, a koji nisu. Zadarska crkva u tom kontekstu slijedi opću sinodalnu praksu i u radu se ukazuje na tri sinode koje su donijele odredbe o pridržanim slučajevima: prva je zasjedala 1598., druga 1663., a treća 1680. godine. Sinoda 1680. godine doslovno je preuzela onaj tekst koji donose sinodalni akti 1663. godine. Njihov prijevod na hrvatski jezik priređen je za one svećenike Zadarske nadbiskupije koji nisu dovoljno poznavali latinski jezik, a objavila ga je prije nekoliko godina Grozdana Franov-Živković. Popis rezerviranih slučajeva Zadarske crkve sadržajno se naslanja na odredbe prijašnjih sinoda i propisa Rimske kurije iz 1601., 1602. i 1661. godine: sinoda 1598. godine donijela je čak 28 rezerviranih slučajeva, dok ih je dijecezanska sinoda 1663. i ona 1680. godine nastojala umanjiti ujedinjujući na više mjesta dva u jedan rezervirani slučaj.

Ključne riječi: pridržani slučajevi, zadarske dijecezanske sinode, odluke sinoda, Zadar, Zadarska crkva, rani novi vijek.

\section{UVOD}

Upravo u naše vrijeme, kada je svjetskoj javnosti postala poznata proširenost pedofilnih klerika i nepovjerenje u crkveno vodstvo u zapadnom svijetu (Europi i Americi) dosegnulo nepregledne razmjere, izbila je na površinu duboka kriza klera. Ona je uzdrmala temelje današnjih crkvenih struktura, narušila je povjerenje u njih i postalo je aktualno stoljetno pitanje primjerne kazne: kako i na koji način kazniti one klerike i laike koji su počinili zlodjela protiv Boga i svojega bližnjeg? Među njima se izričito pokušava zaštiti nevinu djecu i naglašava se zabrana bilo kakvog seksualnog odnosa s njima (coeuntes cum brutis). U tom kontekstu, bez ikakve pretjeranosti, nameće se pitanje pridržanih slučajeva i djelotvorne primjene sakramenta pokore. Štošta se danas promijenilo u crkveno-pravnoj praksi. Dok je prije svaki teološki priručnik posjedovao jedno posebno poglavlje o pridržanim slučajevima (de casibus 
reservatis), ${ }^{1}$ danas su oni skoro nestali iz svakodnevne crkvene prakse. Tema se, usprkos njezinoj aktualnosti u današnjim crkvenim institucijama, promatra $s$ povijesne strane, u kontekstu zadarske sinodalne tradicije, i to s osobitim pogledom na odredbe o pridržanim slučajevima koje su, u jednom razdoblju od nekih osamdeset godina, donesene na tri dijecezanske sinode: prva je zasjedala 1598., druga 1663., a treća 1680. godine.

Općenito, dijecezanske sinode bile su mjesta preko kojih se poslije Tridentskog sabora (1546. - 1563.) sprovodila neophodna reforma, manje in capite (glave), a puno više in membris (udova), tj. manje predvoditelj biskupije (mjesni biskup), a daleko intenzivnije dijecezanski kler i osobito laici. Takva praksa proizlazi iz same definicije dijecezanske sinode, jer na njoj je mjesni ordinarij centralna figura koji pokušava sprovesti obnovu na teritoriju povjerene biskupije. ${ }^{2}$ Ona zapravo predstavlja zakonodavni organ kojim se biskup može služiti po vlastitom nahođenju, a često su one zapravo i služile toj svrsi. ${ }^{3}$ U Zadarskoj crkvi takva se praksa može zorno vidjeti, u pozitivnom kao i negativnom svjetlu, na primjeru

$1 \quad$ Kratki pregled donosi Otto SCHEeL, Čl.: Casus reservati, Die Religion in Geschichte und Gegenwart, 1, Tübingen, 1909., 1595 - 1600; André BRIDE, Čl.: Réserve. Cas réservés, Dictionnaire de théologie catholique, 13, Paris, 1937., 2441 - 2461; Georg MAY, Čl.: Reservation, Lexikon für Theologie und Kirche, 8, Freiburg, 1963. (pretisak 1986.), 1248 - 1249; Georg MAY, Čl.: Reservation, Lexikon für Theologie und Kirche, 8, Freiburg-Basel-Roma-Wien, 1999. (pretisak 2009.), 1120 - 1121; Roberto PuzA, Čl.: Reservation, Lexikon des Mittelalters, 7, München-Zürich, 1995., 754.

2 O dijecezanskim sinodama donosi pojedinosti Paul Hinschius, Das Kirchenrecht der Katholiken und Protestanten in Deutschland. System des katholischen Kirchenrechts mit besonderer Rücksicht auf Deutschland, vol. III, Berlin, 1883. (pretisak Graz, 1959.), 582 - 603; Jean GAUDEMET, Le Gouvernement de l' Eglise à l'époque classique. IIe Partie: Le gouvernement local, Paris, 1979., 173 180; Il Sinodo diocesano nella teologia e nella storia: atti del convegno di studi, Catania, 15-16 maggio, 1986, Acireale, 1987.; Peter Wiegand, Diözesansynoden und bischöfliche Statutengesetztgebung im Bistum Kammin. Zur Entwicklung des partikularen Kirchenrechts im spätmittelalterlichen Deutschland, Forschungen zur Pommerischen Geschichte, 32, Köln-Weimar-Wien, 1988., 8 - 48; Norbert Wiтsch, Synodalität auf Ebene der Diözese. Die Bestimmungen des universalkirchlichen Rechts der Lateinischen Kirche, Kirchen- und Staatskirchenrecht, 1, Paderborn-München-WienZürich, 2004., 50 - 137; Sabine Demel, Handbuch Kirchenrecht. Grundbegriffe für Studium und Praxis, 2. durchgesehene und aktualisierte Auflage, Freiburg, 2013., 125 - 129; Heribert Schmitz, Die Konsultationsorgane des Diözesanbischofs, Handbuch des katholischen Kirchenrechts, dritte, vollständig neubearbeitete Auflage, prir. Stephan Haering, Wilhelm Rees, Heribert Schmitz, Regensburg, 2015., 620 - 637, ovdje 622 - 626.

3 U crkvenoj praksi nije se ni poslije Drugog Vatikanskog sabora (1962. - 1965.) znatnije izmijenio odnos mjesnog biskupa prema dijecezanskoj sinodi. Crkveni zakonik iz 1983. godine precizno određuje podređenost dijecezanske sinode mjesnom biskupu. Ona je još uvijek ostala samo savjetodavni organ, a ima samo toliko ovlasti koliko joj ih daje biskup. Njezine odluke vrijede za biskupiju samo ako ih je mjesni biskup kao takve potvrdio. Nikola ŠKALABRIN, Crkvena zajednica i strukture suodgovornosti, Bogoslovska Smotra, 69, Zagreb, 1997., $461-472$; N. WitsCH, Synodalität auf Ebene der Diözese, 50 - 137; S. DemeL, Handbuch Kirchenrecht, 125 - 129; H. Schmitz, Die Konsultationsorgane des Diözesanbischofs, $622-626$. 
dostupnih vrela s pojedinih dijecezanskih sinoda, npr. ona koja je zasjedala 1460., 1566., 1598., 1647., 1663. ili ona iz 1680. godine. ${ }^{4}$

U kontekstu zadane teme situacija u Zadarskoj crkvi dio je općih crkvenih i društvenih strujanja kada su mjesni nadbiskupi preko dijecezanskih sinoda rezervirali pojedine slučajeve: njihovi propisi nisu samo dodirivali crkvenu situaciju ili samo kler, nego su duboko zadirali u socijalnu strukturu društva, a samim time i u gospodarske (ne)prilike koje su se tijekom druge polovice 16. i prvoj polovini 17. stoljeća na zadarskom području, uslijed otomanskih prodiranja i njihova zauzimanja velikog dijela zadarskog područja, znatno izmijenile. Sinodalni zaključci dio su tog razvojnog procesa, a tri zadarske dijecezanske sinode koje su održane u razdoblju od preko osamdeset godina pokazuju sadržajno znatne sličnosti, dapače sinoda 1680. godine doslovno je preuzela odredbu o pridržanim slučajevima koja je obznanjena na dijecezanskoj sinodi 1663. godine. Na sljedećim stranicama u shematskom prikazu njihovih tekstova to se odmah primjećuje jer se njihove odredbe sadržajno jedne od drugih neznatno razlikuju. Dijecezanska sinoda koju je sazvao nadbiskup Minucije de Minucci (1596. - 1604.)5 25. rujna 1598. godine je originalna i njezine zaključke već je objavio isusovac Daniele Farlati, ${ }^{6}$ te na temelju jednog suvremenog prijepisa koji je danas pohranjen u

4 Usp. Zvjezdan STRIKA, Zadarske sinode u svjetlu povijesnih vrela, Sedamnaest stoljeća Zadarske crkve. Zbornik radova sa znanstvenog skupa o 1700. godišnjici mučeništva sv. Stošije (Anastazije), Zadar, 16.-18. studenog 2004., sv. 1: Od ranokršćanskog razdoblja do pada Mletačke Republike, ur. Livio Marijan, Zadar, 2009., 45 - 104, ovdje 76, 80 - 83, 93 - 98; Zvjezdan STRI KA, Sinoda zadarske crkve 1647. godine, Croatica Christina Periodica, 29, Zagreb, 2005., 43 - 60; Zvjezdan STRI KA, Pokušaj suzbijanja glagoljice na Zadarskoj sinodi 1460. godine, Croatica Christiana Periodica, 34, Zagreb, 2010., 29 - 38; Zvjezdan STRIKA, Die Diözesansynoden von Zadar unter Erzbischof Muzio Callini mit der Edition der synodalen Beschlüsse aus dem Jahre 1566, Begegnung der Kirche in Ost und West im Spiegel der synodalen Strukturen. Festschrift für Petar Vrankić zum 70. Geburtstag, prir. Johannes Grohe, Gregor Wurst, Zvjezdan Strika, Hermann Fischer, St. Ottilien, 2017., 237 - 291; Zvjezdan Strika, Zadarska dijecezanska sinoda 1598. godine, Croatica Christiana Periodica, 43 , Zagreb, 2019., 41 - 57.

5 Pojedinosti o nadbiskupu Minucciju donosi Federico Altan, Memoria intorno alla vita di Monsignor Minuccio Minucci arcivescovo di Zara, Venezia, 1757.; Daniele Farlati, Illyricum sacrum, V, Venetiis, 1775., 142 - 144; Simone Gliubich, Dizionario biografico degli uomini illustri della Dalmazia, Vienna-Zara, 1856. (pretisak Bologna, 1974.), 213 - 214; Carlo Federico Bianchi, Zara Cristiana, sv. I, Zara, 1877., 64 - 66; Alberto Marani, Atti pastorali di Minuccio Minucci, arcivescovo di Zara (1596-1604), Roma, 1970., IX - XXI (Introduzione); Vincenzo di RUzZA, Minuccio Minucci di Serravalle e la sua famiglia, I Minucci. Arcivescovi, letterati e Cavalieri di Malta. Atti del Convegno Internazionale 6 maggio 2000. Collegio San Giuseppe di Vittorio Veneto, prir. Mario Ulliana, Venezia, 2000., 25 - 59; Alexander Koller, Minuccio Minucci (1551-1604). Ein Diplomat in päpstlichen und bayerischen Diensten, Bayerische Römer - römische Bayern. Lebensgeschichten aus Vor- und Frühmoderne, prir. Rainald Becker, Dieter J. Weiß, St. Ottilien, 2016., 249 - 274; Josip VRANDEČIć, Zadarski nadbiskup Minuccio Minucci i njegova jadranska misija, Zagreb, 2017., 11 - 339.

6 D. FARLATI, Illyricum sacrum, V, $144-154$. 
Njemačkom povijesnom institutu u Rimu još jednom ih je publicirao Alberto Marani. ${ }^{7}$ Akti drugih dviju dijecezanskih sinoda ostali su do danas u rukopisu: zaključci zadarske dijecezanske sinode koju je sazvao nadbiskup Teodor Balbi (1656. - 1669.) $)^{8}$ 1663. godine pohranjeni su u Znanstvenoj knjižnici u Zadru, ${ }^{9}$ a njihov ovjerovljeni prijepis iz 1863. godine u Arhivu Zadarske nadbiskupije. ${ }^{10}$ Jedan prijevod sinodalne odredbe o pridržanim slučajevima dostupan je danas u Arhivu Hrvatske akademije znanosti i umjetnosti, sig. br. IVa 80/24. ${ }^{11}$ Njega je, prije nekoliko godina, objavila Grozdana Franov-Živković. ${ }^{12}$ Akti zadarske dijecezanske sinode koju je 1680. godine sazvao zadarski nadbiskup Ivan Evanđelist Parzaghi (1669. - 1688.) ${ }^{13}$ dostupni su danas samo u prijepisu iz 1863. godine, a pohranjeni su $u$ arhivu Zadarske nadbiskupije. ${ }^{14}$

\section{A. Marani, Atti pastorali di Minuccio Minucci, 65 - 92.}

8 Nadbiskup Teodor potjecao je iz ugledne plemićke obitelji Balbi, studirao je u Padovi gdje je stekao naslov doktora crkvenog i civilnog prava. Kratko vrijeme bio je prepozit crkve sv. Nazarija i Celza u Bresciji. Papa Aleksandar VII. (1655. - 1667.) imenovao ga je 18. rujna 1656. godine nadbiskupom Zadarske crkve, pošto je nadbiskupska stolica ostala upražnjena smrću nadbiskupa Florija. Palij mu je uručio osorski biskup Ivan de Rubeis (1653. - 1657.). D. FARLATI, Illyricum sacrum, V, 164 165; C. F. Bianchi, Zara Cristiana, I, 69 - 70; C. F. BiAnchi, Fasti di Zara religioso-politico-civile dell 'anno 1184 av. Cr. Sino all'anno 1888 dell'era volgare, Zara, 1888., 96 - 98; Eduard Peričić, Balbi, Hrvatski biografski leksikon, 1 (A-Bi), Zagreb, 1983., 385; Lovorka Čoralı́́, Prilozi životopisu zadarskoga nadbiskupa Teodora Balbija (1656. - 1669.), Croatica Christiana Periodica, 20, Zagreb, 1996., 83 - 91; Zvjezdan STRIKA, „Catalogus episcoporum et archiepiscoporum urbis Iadertinae” arhiđakona Valerija Pontea, RZHAZd, 48, Zagreb-Zadar, 2006., 81 - 185, ovdje 181.

$9 \quad$ Na koricama je naveden naslov: Synodus Prima Illustrissimi ac Reverendissimi Domini Theodri Balbi Miseratione Divina Archiepiscopi Iadrensis, 1663., Znanstvena knjižnica u Zadru, Ms 843.

10 HR-Arhiv Zadarske Nadbiskupije - 16/6, Prva biskupska sinoda (Synodus dioecesana prima). Usp. Oliver Modrić, Josip Kolanović, Vodič arhiva Zadarske nadbiskupije, Zadar, 2013., 90.

11 Njegov opis donosi Ivan MiLČE TIĆ, Hrvatska glagoljska bibliografija, Starine JAZU, 33, Zagreb, 1911., 283; Vjekoslav ŠTefanić, Glagoljski rukopisi Jugoslavenske akademije, I dio, Zagreb, 1969., 211.

12 Grozdana Franov-Žıvković, Glagoljske moralno-kazuističke odredbe ninskih biskupa, 17. i 18. st., $R Z H A Z d$, 57, Zagreb-Zadar, 2015., 185 - 216, ovdje 186, bilj. 4.

13 Ivana Evanđelistu Parzaghija iz Cremone, franjevca i doktora teologije, imenovao je papa Klement IX. (1667. - 1669.) 19. kolovoza 1669. godine novim zadarskim nadbiskupom. Ovaj je nadbiskup po uputama Tridentskog sabora pokušao provesti obnovu nadbiskupije, pošto je njezino kopneno područje oslobođeno. Osobno je obilazio pojedine župe podupirući obnovu porušenih župa. Umro je u Zadru 24. kolovoza 1688. i sahranjen je u crkvi sv. Franje. V. Pon te, Historia ecclesiae Iadrensis, Znanstvena knjižnica u Zadru, Ms 112, fol. 27ª I. TANZLINGHer ZANotTi, La dama cronologica, Znanstvena knjižnica u Zadru, Ms 446, fol. 63 - 64ª ; Guerrino Ferrante, Discrizione de' vescovi e arcivescovi della metropolitana di Zara e dal loro operato con moltissime varie dichiarazioni degane a sapersi dell'anno 388 fino al 1754, Znanstvena knjižnica u Zadru, Ms 738, fol. 22; D. FARLATi, Illyricum sacrum, V, 165 - 166; C. F. BIANCHI, Zara Cristiana, I, 70 - 71; Lovorka Čoralić, Prilog životopisu zadarskog nadbiskupa Ivana Evanđelista Parzaghija (1669. - 1688.), Croatica Christiana Periodica, 31, Zagreb, 2007., 57 - 66. 


\section{OPĆI POGLED NA RESERVATIO CASUUM}

Manifesta peccata non sunt occulta correctione purganda (javni grijesi ne mogu se opraštati tajnom pokorom) (correctio) - tako barem glasi jedno, još iz 9. stoljeća načelo koje je 1234. godine preuzeo Liber Extra, a s njime je prešlo u opću crkvenu praksu. ${ }^{15}$ Ono je tijekom kasnijih stoljeća utjecalo na primjenu pokore i izricanja pojedinih kazni zbog počinjenih prijestupa. Među njima posebno mjesto zauzimaju pridržani slučajevi savjesti koji imaju svoje početke sredinom 11. stoljeća kada nestaje iz crkvene prakse pokora s izrazito strogim kaznama. Njihovo uvođenje trebalo je djelotvornije preduhitriti opasnost ćudorednog opadanja pošto su izostale oštre presude. Njihova primjena nije se, dakle, sastojala u tome da bi se za počinjena zlodjela (grijehe) još daleko strože osudilo ili da bi se donosile drakonske presude, nego da bi se u budućnosti takvi ili slični prijestupi mogli uspješnije preduhitriti. Sinodalne odredbe imale su odgojnopedagoški karakter stvarajući kod svih vjernika (klerika i laika) svijest vlastite odgovornosti jer prekršaji predstavljaju zlodjela ne samo protiv Boga, nego i protiv svojega bližnjeg te njegovih materijalnih dobara. Zbog njihova iznimno velikog značenja teški prijestupi rezervirali su se rimskom prvosvećeniku, a to znači da je samo on mogao pokornika odriješiti od počinjenih grijeha: svaki pokornik trebao je osobno putovati u Rim gdje bi na grobovima apostolskih prvaka, Petra i Pavla, dobio odrješenje. Realna praksa ipak je izgledala nešto drugačija te kako bi se vjernike oslobodilo od velikih novčanih izdataka i često dalekih putovanja, preneseno je odrješenje na mjesne ordinarije.

Upravo generalni i pokrajinski sabori te dijecezanske sinode mjesta su koja su svojim odredbama određivala koji slučajevi savjesti trebaju biti rezervirani mjesnom biskupu, a koji ne. Oni su za temu naše studije najvažniji izvor i pokazuju kontinuitet sinodalne prakse: prvu među njima donijela je Sinoda u Clermontu koja je zasjedala 18. studenog 1130 . godine pod predsjedanjem pape Inocenta II. (1130. - 1143.). U 13. zaključku izričito se navodi da kažnjavanje namjernog podmetanja požara može prekršitelju biti samo onda oprošteno pošto se

14 Constitutiones et Decreta Illustrissimi ac Reverendissimi Domini Domini Evangelistae Parzaghi Miseratione Divina Archiepiscopi Iadrensis, In sua prima dioecesana synodo promulgatae die 13. 14. et 15. mensis Octobris 1680., HR - Arhiv Zadarske nadbiskupije - 16/6, Biskupska sinoda (Synodus dioecesana) za nadbiskupa E. Parzaghi. Usp. također Velimir BlažEvić, Concilia et synodi in territorio hodiernae Jugoslaviae celebrata, Vicetiae, 1967., 123 - 124; Velimir BlažEvić, Crkveni partikularni sabori $i$ dijecezanske sinode na području Hrvatske i drugih južnoslavenskih zemalja, Croatica Christiana Fontes, 27, Zagreb, 2012., 236; Z. STRIKA, Zadarske sinode, 96; O. MODRIĆ, J. Kolanović, Vodič arhiva Zadarske nadbiskupije, 91.

15 Lib. V Tit. 38 De poenitentiis et remissionibus, Exp. 1, Corpus iuris canonici, II, prir. Aemilius Friedberg, Lipsiae, 1879. (pretisak Graz, 1959.), 884. 
nadoknadi nanesena materijalna šteta. Ako bi mu mjesni biskup podijelio oprost prije negoli je nadoknađena šteta, tada je biskup bio osobno dužan nadoknaditi ju. ${ }^{16}$ Zaključak se u Francuskoj brzo proširio, a Sinoda u Reimsu 1131. godine izričito je obnovila 13. zaključak sa Sinode u Clermontu. ${ }^{17}$

Drugi Lateranski sabor koji je zasjedao 1139. godine, i danas mu se pridaje u Katoličkoj crkvi ekumenski karakter, skladno se uklapa u taj proces. U 18. odredbi izričito se govori protiv namjernog podmetanja požara, a ako bi neki biskup podijelio počinitelju oproštenje prije negoli je namirena počinjena šteta, tada je vrijedila biskupu ista kazna kao i ona koju je već izrekla Sinoda u Clermontu. ${ }^{18}$ Sabor, dakle, ne donosi novi zaključak niti svojim sadržajem postrožuje konkretnu praksu, nego samo obnavlja sankcije koje su već izrečene i potiče mjesne biskupe neka razumno podjeljuju oprost.

Na njih se sadržajno naslanja Sinoda u Londonu koja je zasjedala 1142. godine. Ona proširuje rezervaciju na još nekoliko slučaja: podmetanje požara, velike krađe (fures atrociores) i krivokletnika na štetu drugoga rezervirani su mjesnom biskupu. ${ }^{19}$ Sinoda u Saintesu 1280. godine rezervirala je uz one s Londonskog sabora još više prijestupa mjesnom biskupu: zavođenje i seksualno općenje $s$ monahinjama, grijehe protiv prirode, krivokletstvo, incest, krivotvorenje isprava, čarobnjaštvo i oskvrnuće crkava. Uz njih je sinoda u južnofrancuskom Riezu 1285. godine unijela među pridržane slučajeve još i odredbu protiv pobačaja. ${ }^{20} \mathrm{Na}$ njih se misaono i sadržajno naslanja Sabor u Lamberthu koji je 1281. godine uz druge prijestupe rezervirao mjesnom ordinariju javna i potajna

16 Usp. Johannes Dominicus MANsi, Sacrorum conciliorum nova et amplissima collectio, 21: ab anno 1109 ad annum 1166 inclusive, Paris, 1901 (pretisak Florentiae, 1961.), 440; Carl Joseph von Hefele, Conciliengeschichte: nach den Quellen bearbeitet, sv. V, zweite vermehrte und verbesserte Auflage besorgt von Alois KNÖPfler, Freiburg i. Br., 1886., 410 - 411; Carl Joseph von HefELE, Henri LeClercQ, Histoire des conciles d'après les documents originaux, V, Paris, 1912. (pretisak 1973.), 688.

17 Usp. C. J. v. Hefele, Conciliengeschichte: nach den Quellen bearbeitet, V, 419; Carl Joseph von Hefele, Henri Leclerce, Histoire des conciles d'après les documents originaux, V, 699.

18 Usp. Conciliorum Oecumenicorum Decreta, curantibus Giuseppe Alberigo, Josepho A. Dossetti, Pericles-P. Joannou, Claudio Leonardi, Paulo Prodi, consultante Hubertus Jedin, edidit Istituto per le Scienze Religiose, treće izdanje, Bologna, 1973., njemački prijevod sv. II: Konzilien des Mittelalters: Vom Ersten Laterankonzil (1123) bis zum fünften Laterankonzil (1512-1517), prir. Josef Wohlmuth, Paderborn-München-Wien-Zürich, 2000., 201; Conciliorum Oecumenicorum Generaliumque Decreta, vol. II/1: The general councils of latin christendom from Constantinople IV to Pavia-Siena (869 - 1424), prir, Alberto Melloni, Turnhout, 2013., 110 - 111.

19 Usp. Joseph Gris AR, Die Reform der „Reservatio casuum“ unter Papst Clemens VIII., Saggi storici intorno al papato dei Professori della Facoltà Storia ecclesiastica, Miscellanea Historiae Pontificiae, 21, Roma, 1959., 305 - 385, ovdje 308.

20 Usp. Wolfgang P. Müller, Die Abtreibung. Anfänge der Kriminalisierung 1140-1650, Köln-WeinarWien, 2000., 78. 
ubojstva. ${ }^{21}$ Pokrajinski sabor u Raveni 1286. godine podredio je $s$ osmim zaključkom (de criminibus et dilectis specialiter episcopis reservatis) isto tako slične slučajeve biskupu dodajući njima još i psovku, prekršaj zavjeta, davljenje djece u vlastitom bračnom krevetu, seksualni odnos sa životinjama (grijeh protiv naravi), rodoskvrnuće, krivotvorenje vjerodostojnih povelja, zavođenje nevinih redovnica, krivokletstvo i nezakonito prisvajanje tuđe imovine. ${ }^{22} \mathrm{Na}$ njih se naslanja dijecezanska sinoda koja je zasjedala 1327. godine u gradu Konstanzu na Bodenskom jezeru i ona sadržajno, sličnim riječima, ponavlja odredbe koje su donesene na već prije spomenutim saborima. ${ }^{23}$ Praksu proširivanja rezerviranih slučajeva nastavio je Pokrajinski sabor u Beneventu 1374. godine dodajući još nekoliko rezerviranih slučajeva. ${ }^{24}$

Takvim mjerama pridružio se i papa Bonifacije VIII. (1294. - 1303.) koji je rezervirao neke slučajeve mjesnom biskupu, a još detaljnije ih je razvio njegov nasljednik Benedikt XI. (1303. - 1304.) konstitucijom Inter cunctas sollicitudines 17. veljače 1304. godine. ${ }^{25}$ Njegov nasljednik Klement V. (1304. - 1315.), koji se trajno nastanio u južnofrancuskom Avignonu, obnovio je još jednom odredbe pape Bonifacija VIII., a tijekom sljedećih stoljeća prihvaćeno je pravo rezerviranja odrješenja pojedinih grijeha mjesnom biskupu. Tek je sukob izazvao engleski filozof i teolog John Wycliffe (1330. - 1384.) koji je u svojim postavkama negirao pridržane slučajeve. ${ }^{26}$

Tijekom 14. stoljeća proširuju se u crkvenoj praksi sve više i više rezervirani slučajevi. Oni su se umnožavali, ali otprilike ih je bilo negdje oko trideset. Njihovo praktično primjenjivanje nije bilo uspješno. Talijanski dominikanac i kasniji nadbiskup firentinski Antonius (Antonin) (1389. - 1459.) je, pozivajući se na bulu Dudum pape Klementa V., naveo u svojoj Summa theologica moralis da postoje različita mišljenja među teolozima: jedni u svojem prikazu imenuju više rezerviranih slučajeva, a drugi manje. $U$ pravilu su se razlikovali rezervirani slučajevi de iure i de consuetudine. Kao de iure rezervirane slučajeve priznaju mnogi autori one koje navodi bula pape Benedikta XI.: grijesi klerika zbog

21 Usp. J. Grisar, Die Reform der „Reservatio casuum“ unter Papst Clemens VIII., 308.

22 J. Grisar, Die Reform der „Reservatio casuum“ unter Papst Clemens VIII., 314 - 315.

23 ... puta humicidia, sacrilegia, incestus, stupra virginum, peccata contra naturam, machinaciones manum in clericos vel parentes, vota fracta, et similia nobis et poenitentiario nostro reservatur punienda. Friederike Neumann, Öffentliche Sünder in der Kirche des späten Mittelalters. Verfahren, Sanktionen, Rituale, Köln-Weinar-Wien, 2008., 43.

24 Usp. J. Grisar, Die Reform der „Reservatio casuum“ unter Papst Clemens VIII., 308.

25 Usp. Extravagantes communes 1 V, tit. 7, de privilegiis, Corpus iuris canonici, II, c. 1296 cc.

26 Usp. Jürgen KLEIN, John Wickliffe und die Verweltlichung des Katholizismus im spätmittelalterlichen England, Zeitschrift für Religions- und Geistesgeschichte, 39, Leiden, 1987., $226-252$. 
kojih se gubi klerički stalež, podmetanje požara, grijesi zbog kojih se nameće velika pokora i na kraju slučajevi zbog kojih se izriče izopćenje iz crkvenog zajedništva. Poenitentia solemnis se, kako navodi utjecajni Antonin, više ne upotrebljava. Kao slučajevi de consuetudine rezerviraju se mjesnom biskupu samo oni slučajevi koje navodi bula Inter cunctas sollicitudines: namjerno ubojstvo, krivotvorenje isprava, povređivanje crkvene slobode, oskvrnjenje crkvenog imuniteta, mađioničarstvo (čarobnjaštvo), proricanje budućih događaja i sudbine (gatanje). ${ }^{27}$

Odnos prema rezerviranim slučajevima savjesti i njihovoj primjeni u crkvenoj praksi nije se bitnije promijenio sljedećih stotinu godina. Tek se Tridentski sabor (1545. - 1563.) pozabavio pitanjem pridržanih slučajeva i na svojem 14. zasjedanju u zaključku 7, de poenitentia, obznanio je točne odredbe o slavljenju sakramenta svete pokore. ${ }^{28}$ Usmjeren protiv protestantskih strujanja koji su ponajviše dolazili iz njemačkih zemalja zaključio je sabor: „Ako bi netko tvrdio, biskupi ne bi imali po svojoj službi pridržati slučajeve u odnosu na izvanjsko zajedničko dobro i zbog toga ne bi preduhitrili slučajeve rezervacije, da jedan svećenik od suzdržavanih slučajeva stvarno podijeli odriješenje, neka bude izopćen. “29 Sabor, u svojoj argumentaciji, izvodi rezervaciju iz absolucije sakramenta pomirenja sljedećim riječima: „Budući pak da narav i način rada suda traži, kako bi se donijela presuda prema podložnicima, a (takvo) je uvjerenje uvijek postojalo u Božjoj crkvi, a ovaj sabor potvrđuje da je to najistinitije, da ne bi bilo ni od kakvog značenja ono odrješenje koje bi svećenik izrekao onome za kojeg nema niti redovnu niti prenijetu jurisdikciju.“ Zatim nadalje određuje sabor: „Našim se svetim ocima pak činilo da je za pravilno ponašanje kršćanskog puka od velikog značenja da neke strasnije i teže grijehe ne odrješuju svi svećenici, nego samo vrhovni svećenici. Zbog toga vrhovni svećenici mogu, u skladu s najvišom ovlašću koja im je dana u Crkvi, svom posebnom sudu pridržati neke teže slučajeve grijeha. Ne smije se naime sumnjati, jer je sve što je od Boga uređeno [usp. Rim 13,1], da to ista smije i svaki biskup u svojoj biskupiji, ne za razaranje nego za izgradnju [usp. 2 Kor 10,8; 13,13], snagom veće ovlasti koja mu je dana prema podređenima, u usporedbi s nižim svećenicima, posebno pak u odnosu na one (grijehe) s kojima je povezana kazna izopćenja. To pridržavanje grijeha, u skladu je s

27 Pojedinosti donosi F. Neumann, Öffentliche Sünder in der Kirche des späten Mittelalters, 37.

28 Pojedinosti donosi Paolo Prodi, Eine Geschichte der Gerechtigkeit. Vom Recht Gottes zum modernen Rechtsstaat. Aus dem Italienischen von Annette Seemann, zweite Auflage, München, 2005., 217 224.

29. ... si quis dixerit, episcopos non habere jus reservandi sibi casus, nisi quod externam politiam, atque iedo casuum reservationem non probibere quominus sacerdos a reservatis vere absolvat: anathema sit. 
Božjom vlašću te nema snagu samo za vanjski poredak, nego također i pred Bogom [kan. 11]. ${ }^{“ 30}$

U duhu srednjovjekovnih teoloških razmišljanja koji sadržajno prožimaju koncilski tekst ne želi se $s$ rezerviranim slučajevima savjesti razarati dotadašnju crkvenu praksu, nego samo nadograđivati: reservatio cassum vrijedi ne samo za izvanjski poredak (politia) nego i pred Bogom. ${ }^{31} \mathrm{~Pa}$ ipak, koliko god se naglašavala rezervacija pojedinih slučajeva mjesnom biskupu, saborski sudionici bili su svjesni teškoća u praktičnom sprovođenju i odmah se nalaže „da budu biskupi puni razbora prije nego ustanove ovaj ili onaj grijeh pridržanim“" ${ }^{32}$ A kako bi se preduhitrila neprimjerna praksa i prekomjerna zlouporaba, papa Klement VIII. (1592. - 1605.) zahtijevao je 26. svibnja 1593. godine za redovnike ispovjednike da budu učeni, razboriti u prosuđivanju i osobito nadahnuti ljubavlju, što zapravo znači da trebaju imati pred očima konkretnu osobu i tako se prema njoj odnositi.

Praktični učinak bio je skoro neznatan jer velika većina biskupa nije slijedila naputke rimske administracije. Ona je to primijetila i, nezadovoljna dotadašnjim učinkom, Kongregacija koncila po usmenom je naputku pape Klementa VIII. prvi put 9. siječnja 1601. godine, a drugi put u pismu kardinala Aleksandra Medicija 26. studenog 1602. godine pokušala ublažiti slučajeve rezervacije i njenog neprimjernog sprovođenja. Papa je preporučio biskupima veliku razboritost i neka se rezervirani slučajevi savjesti svedu na razumnu mjeru. Mjesnom biskupu trebaju ostati rezervirani samo oni teški i odvratni grijesi čije opraštanje služi održavanju kršćanske discipline i nužno je za spas duša. Izuzetak su samo oni grijesi koji se, svjesno ili nesvjesno, često ponavljaju, a prefekt kongregacije, kardinal Aleksandar Medici, izričito govori neka se kod rezerviranja uzima u obzir dotično područje s njegovom regionalnom tradicijom i, što je vrlo važno naglasiti, vjernici koji na njemu obitavaju. ${ }^{33} \mathrm{U}$ već prije spomenutom dopisu rimske kongregacije od 26. studenog 1602. godine navodi utjecajni kardinal

30 Hrvatski prijevod donosi Zbirka sažetaka verovanja defincija i izjava o vjeri $i$ ćudoređu, prir. Heinrich Denzinger, Peter Hünermann, prev. Ljudevit Plačko, Đakovo, 2001., br. 1686 - 1687.

31 Conciliorum Oecumenicorum Decreta, curantibus Giuseppe Alberigo, Josepho A. Dossetti, Pericles-P. Joannou, Claudio Leonardi, Paulo Prodi, consultante Hubertus Jedin, edidit Istituto per le Scienze Religiose, treće izdanje, Bologna, 1973., njemački prijevod sv. III: Konzilien der Neuzeit, priredio Josef Wohlmuth, Paderborn-München-Wien-Zürich, 2002., 708; Conciliorum Oecumenicorum Generaliumque Decreta, sv. III: The Oecumenical Councils of the Roman Catholic Church from Trient to Vatican II (1545-1965), prir. Klaus Ganzer, Giuseppe Alberigo, Alberto Melloni, Turnhout, 2010., 68.

32 Ante Cikojević, Stara reservacija i novi dekret „Cum experientia”, Bogoslovska Smotra, 8, Zagreb, 1917., 224 - 245, 329 - 349, ovdje: 227.

33 Latinski original dostupan je u Collectanea in usum Secretariae S. Congregationis Episcoporum et Regularium, cura di Andrea Bizzarri, Roma, 1863., 14 - 19. 
Medici da samo oni slučajevi koje donosi bula In coena Domini te još samo pet dodatnih ostaju i dalje rezervirani papi: povreda crkvene slobode, povreda klauzure uženskim samostanima ( $t j$. ako bi netko imao seksualni kontakt s nekom redovnicom u samostanskoj klauzuri), poziv na dvoboj i njegovo sprovođenje, nasilje protiv klerika i kupovanje crkvenih službi (simonija). ${ }^{34}$

Mnogobrojne dijecezanske sinode i pokrajinski sabori su se poslije 1602. godine pozabavili rezerviranim slučajevima donoseći pri tome jednu ili drugu zabranu. Njihov broj ostaje još uvijek nepoznat i prelazi veličinu ove kratke studije. Njemački crkveni povjesničar i profesor na papinskom sveučilištu Gregoriana Joseph Grisar (1886. - 1967.) prikupio je velik dio njih, ${ }^{35}$ ali zasigurno nije uspio sve pronaći. Njemu su ostale nepoznate zadarske dijecezanske sinode iz 1663. i 1680. godine. Što se pak tiče samih rezerviranih slučajeva savjesti, stanje je ostalo nepromijenjeno više od pola stoljeća, a tek je Kongregacija koncila 29. siječnja 1661. godine pokušala umanjiti rezervirane slučajeve savjesti. Ona je savjetovala biskupima neka u konkretnoj praksi budu razboriti i razumni, a u popisu pridržanih slučajeva trebalo ih je biti navedeno deset, najviše dvanaest, kako je to već 1602. godine predlagao kardinal Aleksandar Medici, ostali neka se izbrišu iz popisa. ${ }^{36}$ Očigledno je Rimska kurija pokušavala suzbiti samovolju pojedinih biskupa koji su bez dubljeg teološkog razmišljanja i često bezrazložno rezervirali mnogobrojne slučajeve savjesti, a time su samo opterećivali kanonike penitenicijare koje su djelomično i sami postavljali.

O tome kolikoje odluka rimske administracije imala uspjeha pri djelotvornijem suzbijanju neprimjernog i neodgovornog umnožavanja rezerviranih slučajeva, teško je iz današnje perspektive donijeti objektivan sud bez intenzivnog proučavanja svake pojedine crkvene pokrajine. Jedan od poznatih autora koji se sustavnije bavio pitanjem rezerviranih slučajeva je bio Jacobus de Graffiis koji u svojem prikazu navodi samo petnaest, ${ }^{37}$ dok nasuprot njega Barbosa spominje samo jedanaest slučajeva koji bi i dalje trebali ostati rezervirani mjesnom ordinariju. ${ }^{38}$ Svi ostali trebali bi se izbrisati iz popisa rezerviranih slučajeva.

34 Pojedinosti donosi J. GrisAR, Die Reform der „Reservatio casuum“ unter Papst Clemens VIII., 327.

35 J. GrisAr, Die Reform der „Reservatio casuum“ unter Papst Clemens VIII., 382, bilj. 48.

36 Usp. Martin ŠTiglić, Katoličko pastirsko bogoslovje, I-II, Zagreb, 1886. - 1887., 300; Pavao LoNČAR, Podmetnuće kao reservat i poslije novoga Kodeksa, Bogoslovska Smotra, 11, Zagreb, $1923 ., 316$ 329 , ovdje 317.

37 Jacobus De Graffirs, Decesiones Auraee casum conscientiae, Antwerpiae 1604. U Appendix aureus, 29 donosi autor pojedine rezervirane slučajeve. J. GRISAR, Die Reform der „Reservatio casuum“ unter Papst Clemens VIII., 314 donosi orginalni latinski tekst.

38 Podatak donosi J. Grisar, Die Reform der „Reservatio casuum“ unter Papst Clemens VIII., 314, bilj. 42. 


\section{ODLUKE DIJECEZANSKIH SINODA}

Ako u povijesnom kontekstu pogledamo situaciju u Zadarskoj crkvi koncem 16. i tijekom 17. stoljeća, tada je očigledno da se njezini rezervirani slučajevi savjesti koji su doneseni na dijecezanskim sinodama 1598., 1663. i 1680. godine skladno uklapaju u opća europska strujanja, osobito se sadržajno poklapaju s onima iz susjedne Italije. Ta činjenica nikako ne iznenađuje, Zadar je povezan s mediteranskim podnebljem u sklopu mletačkog dominija, grad je još od 1409. godine integralni dio Mletačke Republike, a uz to sva trojica nadbiskupa koja su sazvala zadarske dijecezanske sinode potjecala su iz Italije. Oni su bili mletački građani i tek su kao nadbiskupi došli u Zadar.

$\mathrm{U}$ ovom kratkom i shematskom prikazu donosimo odluke triju zadarskih dijecezanskih sinoda o pridržanim slučajevima: zaključak sinode 1598. godine već je prije dva puta objavljen (najprije Farlati, a zatim Marani), dok se zaključak sinode 1663. godine, u ovom preglednom članku, po prvi put objavljuje. Njega je, uz neznatne jezične i sadržajne preinake, preuzela Zadarska dijecezanska sinoda 1680. godine. One se razlikuju samo u uvodnoj rečenici, svi ostali rezervirani slučajevi savjesti su potpuno identični.

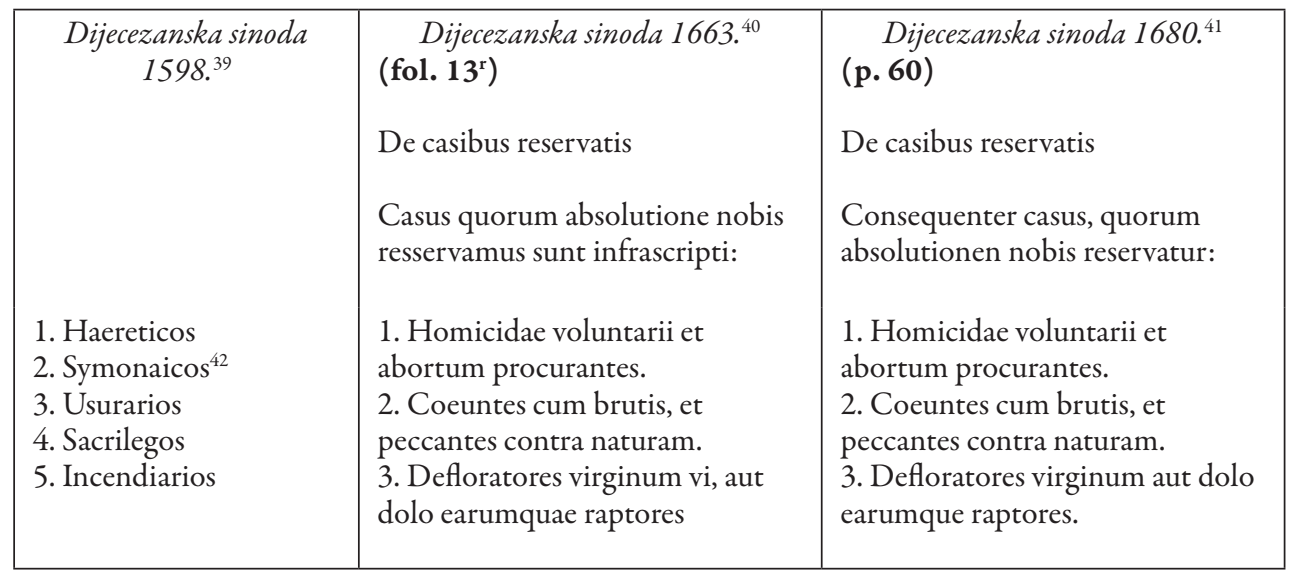

39 De casibus reservatis. D. FARlati, Illyricum sacrum, V, 153 - 154; A. MARANi, Atti pastorali di Minuccio Minucci, 90 - 91.

40 De casibus reservatis, Znanstvena Knjižnica u Zadru, Ms 843, fol. 13 ${ }^{\mathrm{r}-\mathrm{v}}$; HR-Arhiv Zadarske nadbiskupije - 6/6, Biskupska sinoda (Synodus dioecesana), fol. 14 $4^{\mathrm{r}-\mathrm{v}}$.

$\mathrm{Na}$ ovom mjestu zahvaljujem prof. dr. Velimiru Blaževiću koji mi je pomogao pri transkripciji sinodalnih zaključaka.

41 De casibus reservatis. HR-Arhiv Zadarske nadbiskupije - 16/6, Biskupska sinoda (Synodus dioecesana), p. $60-62$.

42 Farlati donosi schismaticos. 


\begin{tabular}{|c|c|c|}
\hline $\begin{array}{l}\text { 6. Latrones seu } \\
\text { grassatores viarum } \\
\text { 7. Homicidas voluntarios } \\
\text { 8. Striges, magos, } \\
\text { veneficos, incantatores, } \\
\text { divinatoris, sortilegos et } \\
\text { ab eis consilium petentes. } \\
\text { 9. Opprimentes } \\
\text { propriam prolem et } \\
\text { sterilitatem aut abortum } \\
\text { quomodolibet curantes. }{ }^{44} \\
\text { 10. In patrem aut } \\
\text { matrem manus violentes } \\
\text { iniicientes. } \\
\text { 11. In mortem sui } \\
\text { coniugis effectualiter } \\
\text { machinantes. } \\
\text { 12. Verberantes clericos, } \\
\text { etiam leviter, vel eos } \\
\text { contumenliis afficientes, } \\
\text { 13. Parentes et nutrices, } \\
\text { qui infantes ante annum } \\
\text { completum secum tenent } \\
\text { in lectio. } \\
\text { 14. Coeuntes cum brutis. } \\
\text { 15. Coeuntes cum } \\
\text { infidelibus. } \\
\text { 16. Peccantes contra } \\
\text { naturam. } \\
\text { 17. Incestum in quarto } \\
\text { aut propinquiori gradu } \\
\text { consanguinitatis aut } \\
\text { affinitatis committentes. } \\
\text { 18. Defloratores, } \\
\text { oppressores et raptores } \\
\text { virginum. } \\
\text { 19. Concubinarios } \\
\text { publicos. }\end{array}$ & $\begin{array}{l}\text { 4. Striges, magi, venefici, } \\
\text { incantantores, divinatores, } \\
\text { superstitioses, medentes, sortilegi, } \\
\text { et ab eis consilium petentes. }{ }^{43} \\
\text { 5. Testes in iuditio falsum iurantes. } \\
\text { 6. Qui infantem ante annum } \\
\text { completum secum in lecto tenent. } \\
\text { 7. Blasphemi ex consuetudine. } \\
\text { 8. Concubinarii publici, vel notorii. } \\
\text { 9. Incestum commitentes } \\
\text { in primo vel secundo gradu } \\
\text { consanguinitatis, vel affinitatis. } \\
\text { 10. Absolvere praesumentes a } \\
\text { peccato, in quo vi poenitentem } \\
\text { participaverunt. } \\
\text { 11. Qui confecto dotali instrumto } \\
\text { seu contractis sponsalibus, } \\
\text { antequam matrimonium per } \\
\text { verba de praesenti ex praescripto } \\
\text { S. R. E. contrahunt, carnaliter se } \\
\text { commissent. } \\
\text { 12. Colloquentes, litteras } \\
\text { aut schedulas mittentes, aut } \\
\text { accipientes, }{ }^{45} \text { monialibus, } \\
\text { conversis, vel educandis sine } \\
\text { licentia ordinarii, exceptis } \\
\text { consanguineis vel affinibus in } \\
\text { primo vel secundo gradu, et } \\
\text { sunt excommunicati. }{ }^{46} \text { Itemque } \\
\text { amicitiam suspectam etiam } \\
\text { per interpositas personas cum } \\
\text { eisdem habentes, quas poenas } \\
\text { et resservationem incurrunt } \\
\text { moniales, conversae, educandae, } \\
\text { in praemissis delinquents, } \\
\text { et internuncii in paefatis } \\
\text { participantes. } \\
\text { 13. Missas in monialium ecclesii } \\
\text { celebrantes, vel confessiones } \\
\text { sacramentales audientes vel alias } \\
\text { functiones ecclesiae exercentes } \\
\text { absque eadem licentia, qui pariter } \\
\text { sunt excomunicati. }\end{array}$ & $\begin{array}{l}\text { 4. Striges, magi, venefici, } \\
\text { incantantores, divinatores, } \\
\text { superstitioses, medentes, sortilegos } \\
\text { et ab eis consilium petentes. } \\
\text { 5. Testes in iuditio falsum iurantes. } \\
\text { 6. Qui infantem ante annum } \\
\text { completum secum in lecto tenent. } \\
\text { 7. Blasphemi ex consuetudine. } \\
\text { 8. Concubinarii publici, vel } \\
\text { notorii. } \\
\text { 9. Incestum commitentes } \\
\text { in primo vel secundo gradu } \\
\text { consanguinitatis, vel affinitatis. } \\
\text { 10. Absolvere praesumentes a } \\
\text { peccato, in quo vi poenitentem } \\
\text { participaverunt. } \\
\text { 11. Qui confecto dotali instrumto } \\
\text { seu contractis sponsalibus, } \\
\text { antequam matrimonium per } \\
\text { verba de praesenti ex praescripto } \\
\text { S. R. E. contrahunt carnaliter se } \\
\text { commissent. } \\
\text { 12. Colloquentes, litteras } \\
\text { aut schedulas mittentes, aut } \\
\text { accipientes, monialibus, conversis, } \\
\text { vel educandis sine licentia } \\
\text { ordinarii, exceptis consanguineis } \\
\text { vel affinibus in primo vel secundo } \\
\text { gradu, et sunt excommunicati. } \\
\text { Itemque (p. 61) amicitiam } \\
\text { suspectam etiam per interpositas } \\
\text { personas cum eisdem habentes, } \\
\text { quas poenas et resservationem } \\
\text { incurrunt moniales, conversae, } \\
\text { educandae, in praemissis } \\
\text { delinquents, et internuncii in } \\
\text { paefatis participantes. } \\
\text { 13. Missas in monialium ecclesii } \\
\text { celebrantes, vel confessiones } \\
\text { sacramentales audentes vel alias } \\
\text { functiones ecclesiae exercentes } \\
\text { absque eadem licentia, qui pariter } \\
\text { sunt excomunicati. }\end{array}$ \\
\hline
\end{tabular}

43 Navedena odredba preuzeta je iz odredbi dijecezanske sinode 1598. godine, a ovdje je donesena pod brojem 8.

44 Farlati donosi procurantes.

45 Slijede precrtane riječi: vel amicitiam suspectam per interpositas personas habentes.

46 Slijede precrtana riječ: easdemque. 


\begin{tabular}{|c|c|c|}
\hline $\begin{array}{l}\text { 20. Sanguinem aut } \\
\text { semen effundentes in } \\
\text { ecclesia. } \\
\text { 21. Quemlibet } \\
\text { coniugatum } \\
\text { contrahentem } \\
\text { matrimonium cum } \\
\text { secunda, vivente uxore. } \\
\text { 22. Mulierem, quae } \\
\text { antequam reddatur } \\
\text { cercior de morte mariti, } \\
\text { secundo contraxerit. } \\
\text { 23. Non solventes } \\
\text { decimas vel fraudem } \\
\text { in solutione ipsa } \\
\text { adhibentes. } \\
\text { 24. Excommunicatum } \\
\text { vel suspectum aut } \\
\text { interdictum in ordine } \\
\text { suo ministrando vel } \\
\text { eos absolventem et } \\
\text { taliter ligatum aliquem } \\
\text { odrinem suscipientem. } \\
\text { 25. Utentes indumentis } \\
\text { ecclesiasticis in larvis vel } \\
\text { in alia re ludicra. } \\
\text { 26. Clericos noctu } \\
\text { per plateas cum armis } \\
\text { grassantes cantilenasque } \\
\text { et musicas sic exercentes. } \\
\text { 27. Accedentes ad } \\
\text { moniales quacumque } \\
\text { de causa sine licentia, } \\
\text { vel mittentes ad ipsas } \\
\text { litteras aut schedulas vel } \\
\text { accipientes pariter sine } \\
\text { licentia, vel accipientes } \\
\text { ab eis munera etiam levia } \\
\text { et levissima, nisi adsit } \\
\text { consensus abatissae. } \\
28 . \text { In ipsarum } \\
\text { monialium ecclesiis sine } \\
\text { licentia celebrantes. }\end{array}$ & 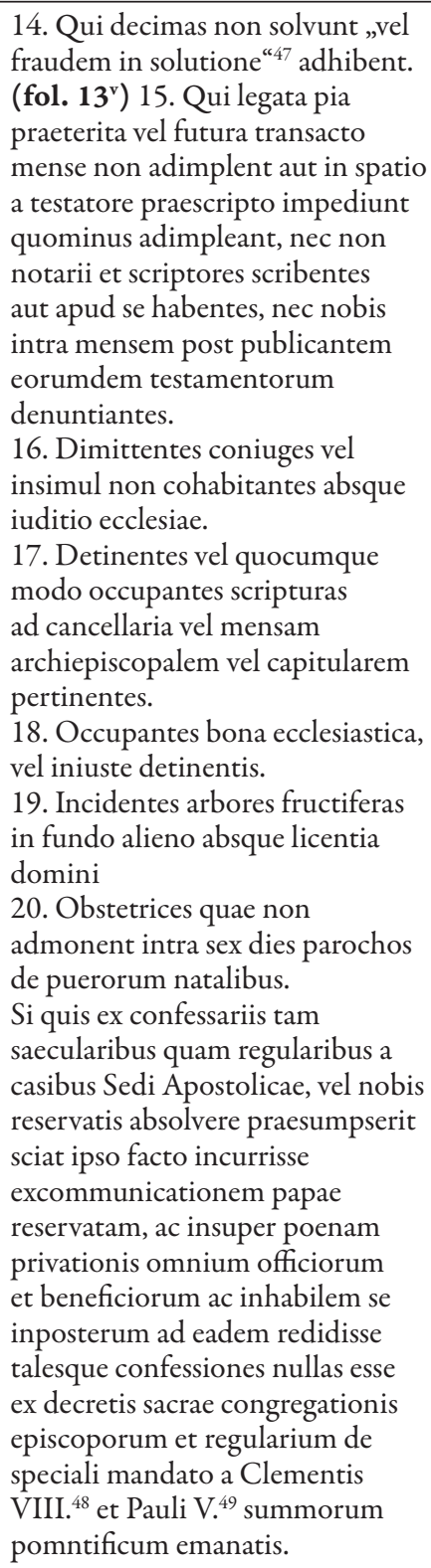 & $\begin{array}{l}\text { 14. Qui decimas non solvunt „vel } \\
\text { fraudem in solutione“ adhibent. } \\
\text { 15. Qui legata pia praeterita } \\
\text { vel futura transacto mense non } \\
\text { adimplent aut in spatio a testatore } \\
\text { praescripto impediunt quominus } \\
\text { adimpleant, nec non notarii et } \\
\text { scriptores scribentes aut apud se } \\
\text { habentes, nec nobis intra mensem } \\
\text { post publicantem eorumdem } \\
\text { testamentorum denuntiantes. } \\
\text { 16. Dimittentes coniuges vel } \\
\text { insimul non cohabitantes absque } \\
\text { iuditio ecclesiae } \\
\text { 17. Detinentes vel quocumque } \\
\text { modo occupantes scripturas } \\
\text { ad cancellariam vel mensam } \\
\text { archiepiscopalem vel capitularem } \\
\text { pertinentes. } \\
\text { 18. Occupantes bona ecclesiastica } \\
\text { vel iniuste detinentis. } \\
\text { 19. Incidentes arbores fructiferas } \\
\text { in fundo alieno absque licentia } \\
\text { domini. } \\
\text { 20. Obstetrices quae parochos } \\
\text { intra sex dies de puerorum } \\
\text { natalibus non admonent. } \\
\text { Si quis ex confessariis tam } \\
\text { saecularibus quam regularibus a } \\
\text { casibus, Sedi Apostolicae vel nobis } \\
\text { reservatis, absolvere praesumpserit, } \\
\text { sciat ipso facto incurrisse } \\
\text { excommunicationem papae } \\
\text { reservatam ac insuper poenam } \\
\text { privationis omnium officiorum } \\
\text { et beneficiorum ac inhabilem se } \\
\text { inposterum ad eadem redidisse } \\
\text { talesque confessiones nullas esse } \\
\text { ex decretis sacrae congregationis } \\
\text { episcoporum et regularium de } \\
\text { speciali mandato a Clementis (p. } \\
\text { 62) VIII. et Pauli V. summorum } \\
\text { pomntificum emanatis. }\end{array}$ \\
\hline
\end{tabular}

47 Navedeni citat preuzet je iz odredbe dijecezanske sinode 1598. godine koji je ovdje donesen pod brojem dvadeset i tri.

48 To su okružnice pape Klementa VIII. (1592. - 1605.), prva je objavljena 9. siječnja 1601., a druga 26. studenog 1602. godine. Usp. ovdje bilj. 33 i 34.

49 To je odredba pape Pavla V. (1605. - 1621.). 


\section{PRIJEVOD SINODALNOG ZAKLJUČKA NA HRVATSKI JEZIK}

U Arhivu Hrvatske akademije znanosti i umjetnosti, sig. br. IVa80/24., pohranjen je jedan list veličine „27,3 x $19,2 \mathrm{~cm}$. Ispisan samo s prednje strane doista nevještim kursivnim pismom koje pokazuje dalmatinske elemente.“50 Tako opisuje Vjekoslav Štefanić (1900. - 1975.) list napisan glagoljicom i na istom mjestu pretpostavlja da je možda nastao u 18. stoljeću. Njega je prepisala i prije nekoliko godina objavila Grozdana Franov-Živković, ali ne navodi kada je tekst točno nastao. ${ }^{51}$ Ona je u sklopu svojeg rada ukazala na pridržane slučajeve savjesti, a kada se usporedi hrvatski prijevod s latinskim originalom koji je donesen na sinodama 1663. i 1680. godine, tada je očigledno da se radi o prijevodu sinodalnog zaključka. Samo nekoliko odredbi neprecizno je prevedeno, iz njih je nešto izostavljeno ili pak na jednom mjestu nadodano. Takav redaktorski zahvat nije bio neophodan, predvoditelj je najvjerojatnije pretpostavljao da je po tome tekst jasniji i budućim klericima shvatljiviji. Prijevod je najvjerojatnije priređen na samoj sinodi 1663. godine ili kratko poslije nje kako bi ga mogli razumjeti i oni svećenici koji nisu poznavali dovoljno latinski jezik, nego su se služili samo hrvatskim jezikom. Ta pretpostavka upućuje na pitanje kada je nastao prijepis koji je danas pohranjen u Arhivu Hrvatske akademije. Točan odgovor nije moguć, a možda je Štefanićeva pretpostavka o kasnijem nastanku dostupnog prijepisa točna, ali je tekst sadržajno nastao znatno ranije. On u hrvatskom prijevodu glasi:

Kazi sahraneni Prisvitlomu Arcibiskupu Zadarskomu

1. Uboistvo povodno i ki bi činijeno da se dite izvrže ${ }^{52}$

2. Puteni grih protiva naravi is živinom

3. Ki uzimaju silom divstvo divoikam ili s privarom ili u našaju

4. Čarovnici i višćice i hanavci ili ždribe meću ili nepodobno žiće ili u nih svita pitanu

5. Koi na sud u krivo se prisižu ili gdi se hoće

6. Žene dicu uza se ligaući prvo godišća

7. Oni koji s običajem Boga psuju i beštimaju

8. Bludnici očiti i poznani

9. Oni koji bi sagrišij puteno u prvo ali u drugo kolino

10. Ki bi odrišijo pokornika dilnika u grihu ako je prima šesto i zapovidi ne može se odrišiti do s(v)e(tog)a oca pape

Vjekoslav ŠTefanIĆ, Glagoljski rukopisi Jugoslavenske akademije, I dio, Zagreb, 1969. 211.

Usp. ovdje bilj. 12.

Navedenu točku je objavio već V. ŠTEFANIĆ, Glagoljski rukopisi Jugoslavenske akademije, I dio, 211. 
11. Koji bi sagrišiu puteno pravo vinčana

12. Koji s koludricami govore brez dopušćena

13. Koji mise govore u crkvah koludraških prez dopušćena

14. Koji ne daju pravo desetine i u noi činine himbu

15. Koji ne ispunuju laši svoih mrtvih

16. Koji proginaju svoe žene od sebe i ne opće zajedno i žene koje biže od muža

17. Koji drže pisma kančilare arcibiskupove

18. Oni koji bi uzima dobra crikovna

19. Oni koji dušu ${ }^{53}$ siku voća brez dopušćena

20. Babe koje se ne jave ${ }^{54}$ parokianu da se je dite rodilo u termen šest dana.

\section{USPOREDBA SINODALNIH TEKSTOVA}

$\mathrm{Na}$ dijecezanskoj sinodi 1598. godine donesena odredba o pridržanim slučajevima bila je u Rimu poznata kako to pokazuju istraživanja Josepha Grisara, ${ }^{55}$ dok je zaključak sinode 1663 . i one 1680. godine ostao do današnjih dana u rukopisu. ${ }^{56}$ Dijecezanska sinoda 1598. godine donijela je čak 28, dok druge dvije sinode donose 20 rezervirana slučajeva, a kako se vidi iz shematskog prikaza svih triju sinoda, očigledno je da su se priređivači sinodalnih tekstova 1663. godine poslužili već pripremljenim sinodalnim tekstom iz 1598. godine. ${ }^{57}$ Reakcija zadarskih nadbiskupa na poticaje umanjivanja rezerviranih slučajeva savjesti koje je poduzela Sveta stolica 9. siječnja 1661. godine urodila je plodom, ali ne tako kako je ona predlagala i kako je ona to od njih očekivala. Njihov broj pokušao se umanjiti ujedinjavanjem dva dotadašnja slučaja u jedan: tako su da dva rezervirana slučaja koja su donesena na dijecezanskoj sinodi 1598. godine (ovdje brojevi 14 i 16) na dijecezanskim sinodama 1663. i 1680. godine sjedinjena u jedan (broj 2). ili pak brojevi 7 i 9 iste sinode ujedinjeni su u prvoj točki. Na taj se način umanjivao samo njihov redni broj, ali se brojčano nije stvarno umanjivao, nego je ostajao isti. Pod jednim te istim brojem nadalje su se bilježila dva pridržana slučaja.

53 V. ŠTEFANIĆ, Glagoljski rukopisi Jugoslavenske akademije, I dio, 211, prepisao je dubu.

54 V. ŠTEFAnIĆ, Glagoljski rukopisi Jugoslavenske akademije, I dio, 211, pročitao je ave.

55 J. Grisar, Die Reform der „Reservatio casuum“ unter Papst Clemens VIII., 305, bilj. 1.

56 Usp. ovdje bilj. 9 i 14.

57 Taj navod potkrjepljuje tekst sinode 1598. godine pod brojem $4 \mathrm{i}$ tekst sinoda 1663. i 1680. godine pod brojem 4. Isto tako, tekst pod brojem 14 istih sinoda pokazuje pozadinu sinode 1598. godine pod brojem 23. Uz njih može se napomenuti i zabrana 12 sa sinoda 1663. i 1680. godine sa zabranom broj 27 sa sinode 1598. godine. 
Svojim sadržajem može se odredba De casibus reservatis dijecezanske sinode 1598. godine podijeliti na nekoliko misaonih cjelina koje u svojoj biti slijede rimske odredbe. Osobito dijecezanske sinode 1663. i 1680. godine slijede prijedloge Kongregacije koncila iz 1602. i 1661. godine naglašujući uz njih i posebnu tradiciju Zadarske crkve:

Prvu grupu čine grijesi koji su usmjereni protiv Boga i kršćanske vjere. Oni su usmjereni protiv rasprostranjenog bogohuljenja, psovanja Boga, Marije i svetaca, ${ }^{58}$ svetokrađe, svekolikog krivovjerja, praznovjerja (proricanje budućnosti, vračanje, čaranje, preklinjanje i magično trovanje), ${ }^{59}$ heretičkih i shizmatičnih strujanja. Ta činjenica nije nebitna. Krivovjerci, kako su se tada uobičajeno oslovljavali muslimani, redovno su posjećivali Zadar, ${ }^{60}$ dok su shizmatici prvenstveno bili pravoslavni koji su s osmanskim prodorom dospjeli na teritorij današnje Zadarske nadbiskupije, a nadbiskupi su ih u duhu tadašnjih unionističkih težnji (reductio schisamticorum) pokušavali privesti katoličkoj vjeri. ${ }^{61} \mathrm{Uz}$ to, u samom je Zadru 1578. godine nadbiskup Natale Venier (1577. - 1588.) prepustio crkvu

58 Zadarska dijecezanska sinoda je 1680. godine donijela zaključak $O$ psovci (De blasphemia). HRArhiv Zadarske nadbiskupije - 16/6, Biskupska sinoda (Synodus dioecesana), p. 6.

59 Takva praksa bila je proširena po Zadarskoj nadbiskupiji. Već je sinoda 1598. godine donijela odredbu $O$ vraćanju i magijskim umijećima (De sortilegiis et magicis artibus). D. FARLATI, Illyricum sacrum, V, 150 - 151; A. MARAnI, Attipastorali di Minuccio Minucci, 82-83;J. VRAndečrć, Zadarski nadbiskup Minuccio Minucci i njegova jadranska misija, 203; Z. STRIKA, Zadarska dijecezanska sinoda, 50. U svojem izvješću ad limina 1609. godine javlja nadbiskup zadarski Viktor Ragazzoni (1604. - 1615.) da blizina pravoslavnog stanovništva i osobito omraženih Osmanlija stvara teška svetogrđa i praznovjerja od čega ni otoci nisu ostali pošteđeni. Među mnogim praznovjernim običajima koji nisu spojivi s kršćanskom vjerom ističe nadbiskup da se na otocima ekshumiraju tijela i vješaju na stabla u lažnoj vjeri da ubuduće njihova djeca neće trpjeti. Congregatio concilii: Relatio ad limina dioecesis Iadrensis anno 1615, AAV, cod. 413A, fol. $20^{\mathrm{r}}-38^{\mathrm{r}}$; Josip Kolanović, Zadarska nadbiskupija prema izvještajima ad limina 1599-1799., Sedamnaest stoljeća Zadarske crkve, 1, 379 - 413, ovdje, 385. Zadarska dijecezanska sinoda 1647. godine donijela je odredbu $O$ praznovjerjima (De superstitionibus). Z. STRIKA, Sinoda zadarske crkve, $52-53$.

60 Dijecezanska sinoda 1598. godine u odredbi O Turcima i njihovu ponašanju (De Turcis eorumque consuetudine) pokušala je preduhitriti kontakte između muslimana i vjernika katolika koji su živjeli pod mletačkom vlašću: ona zabranjuje prenoćište muslimana u kršćanskim kućama i pokazivanje crkvenog posuđa pred njima, zabranjuje bilo kakvo općenje kršćanskih djevojaka s muslimanima kako bi se preduhitrili mogući brakovi među njima. D. FARLAti, Illyricum sacrum, V, 151; A. Marani, Atti pastorali di Minuccio Minucci, 83 - 84; J. VRAndečić, Zadarski nadbiskup Minuccio Minucci i njegova jadranska misija, 203 - 204; Z. STRIKA, Zadarska dijecezanska sinoda, 50 - 51.

${ }_{61}$ Zadarska dijecezanska sinoda 1680. godine donijela je zaključak $O$ grčkom obredu (De ritu graeco). HR-Arhiv Zadarske nadbiskupije - 16/6, Biskupska sinoda (Synodus dioecesana), p. 4 - 5. Takva unionistička strujanja dobila su zamah na Firentskom saboru iz 1439. godine i ostala su službena rimska doktrina sve do Drugog Vatikanskog sabora. Ona danas nisu više prihvatljiva i u katoličkoj teološkoj misli prodire sve više shvaćanje da jedinstvo Crkve nije fuzioniranje, tj. povratak u krilo Katoličke crkve, nego svaka pojedina Crkva treba čuvati svoju vlastitu tradiciju, liturgiju i običaje. 
sv. Ilije Proroka pravoslavnima za slavljenje liturgijskih obreda po bizantskom obredu, ali je i dalje zadržan jedan oltar za slavljenje mise na latinskom obredu. ${ }^{62}$ Djelomično su pravoslavni vojnici stupali u mletačku vojnu službu i državna uprava podjeljivala im je određene privilegije, a njihovi svećenici i monasi bili su podređeni filadelfijskom biskupu koji je rezidirao u Veneciji. ${ }^{63}$

Sinoda iz 1598. godine zabranjuje u petnaestoj točki kontakt s nevjernicima (coeuntes cum infidelibus). Ona ima pred očima odnos prema muslimanima jer su Osmanlije, poslije tzv. Ciparskog rata i državnog razgraničenja između Otomanske Carevine i Mletačke Republike, bili nadomak samog Zadra. ${ }^{64}$ Nasuprot nje, kasnije dijecezanske sinode (1663. i 1680.) ne spominju više takvu zabranu, zasigurno iz praktičnih razloga jer je pučanstvo koje je obitavalo na području pod mletačkom vlašću navezano na područje pod otomanskom vlašću: stanovnici mletačkog područja imali su rodbinske i prijateljske odnose s onima na području pod otomanskom vlašću, oni su usred manjkavosti posjeda imali livade i pašnjake s druge strane granice. Mletački podanici su, uz određene daće, smjeli obrađivati zemlju na području pod osmanskom vlašću ${ }^{65} \mathrm{Njihova}$ međusobna komunikacija i njihova uzajamna gospodarska povezanost bile su neophodne, na korist jedne i druge strane.

Drugu grupu predstavljaju grijesi protiv bližnjeg, njegove časti i njegovih gospodarskih dobara, tj. protiv onih koji su drugim osobama namjerno nanosili materijalnu štetu. Njima se pridružuje i lažno svjedočanstvo. Na prvom su mjestu oni koji su podmetali požare nevinim ljudima kako je to već 1142 . godine odredio sabor u Londonu, a kasnije su njegovo rezerviranje ponavljale mnogobrojne sinode. Na zadarskoj sinodi 1598. godine osuđuje se na trećem mjestu uzimanje kamata na posuđeni novac. Njih kasnije zadarske sinode više ne ubrajaju među rezervirane slučajeve. Poslije njih slijedi zabrana razbojništva ili pak zasjedanja na putovima, tj. robljenje i otimačina koje su bile znatno proširene u Dalmaciji tijekom 16 i 17. stoljeća. Nisu samo otomanski podanici bili ti koji su otimali i krali, nego su to također činili i mletački podanici koji su bili kršćanske vjere. U

62 Usp. C. F. Bianchi, Zara Cristiana, I, 451; Angelo de Benvenuti, Storia di Zara dal 1409 al 1797, Milano, 1944., 129; J. KolAnović, Zadarska nadbiskupija prema izvještajima ad limina, 407; J. VRANDEČIĆ, Zadarski nadbiskup Minuccio Minucci i njegova jadranska misija, 194.

63 Usp. Mile Bogović, Katolička Crkva i pravoslavlje u Dalmaciji za mletačke vladavine, Analecta Croatica Christiana, 14, drugo izdanje, Zagreb, 1993., 98 - 99.

64 Usp. Tomislav Raukar, Ivo Petricioli, Franjo Švelec, Šime Peričić, Zadar pod mletačkom upravom 1409-1997, Prošlost Zadra - knjiga III, Zadar, 1987., 218. Usp. također ovdje u bilj. 60 navedenu literaturu.

65 Usp. Lovorka ČorAlić, Jedan neobjavljeni dokument o suživotu na mletačko-turskoj granici u zadarskom području u XVII. stoljeću, Historijski Zbornik, 45, Zagreb, 1992., 213 - 218. 
tu grupu rezerviranih slučajeva pripada isto tako nepravda krivog svjedočanstva koje ne spominje sinoda 1598. godine nego samo dijecezanske sinode 1663. i 1680. godine.

Među grijesima protiv bližnjeg posebno mjesto zauzima krvna osveta (homicida voluntaria) koju dijecezanske sinode 1663. i 1680. godine smještaju čak na prvo mjesto, dok je sinoda 1598. godine smješta na sedmo mjesto. Obje sinode smještaju je na prvo mjesto, što pokazuje daje ona još uvijek bila proširena u Zadarskoj nadbiskupiji i što je isto tako neophodno naglasiti, kolika je velika važnost pridavana njezinu uspješnijem suzbijanju. Njezina rasprostranjenost nije se osjećala samo u Dalmaciji, nego je poznata i po Zapadnoj Europi tijekom 16. i 17. stoljeća. Isto tako se često prakticirala u Francuskoj i Italiji, kako se vidi iz pisma biskupa Bergama Giambattiste Milanija (1592. - 1611.) koje je poslao 19. veljače 1603. godine u Rim. ${ }^{66}$ Pokrajinski sabor u Besanconu (Burgund) je 24. listopada 1571. godine smjestio krvnu osvetu medu peccata clamantia in coelum. ${ }^{67}$

Trećoj grupi pripadaju nemoralni prijestupi kao što su seksualna razvratnost, nećudorednost i bludnost. To su oni zabranjeni slučajevi koji se odnose na svekolike izvanbračne seksualne radnje. Seksualni odnos muškarca i žene je bio „dozvoljen“ samo u zakonito sklopljenom braku (u crkvi pred svećenikom i svjedocima), a trebao je isključivo služiti rađanju djece: na prvom mjestu zabranjuje se seksualno općenje s malenom djecom, tj. zabranjuje se prakticiranje pedofilije. Na drugom se mjestu zabranjuju grijesi protiv prirode, tj. seksualno općenje sa životinjama, zatim se zabranjuje seksualni odnos s bližom rodbinom, zabranjuje se odnos s muslimanskim nevjernicima, zabranjuje se javni ili potajni konkubinat. ${ }^{68} \mathrm{Uz}$ njih se još strogo zabranjuje oskvrnjivanje djevica.

Među tim propisima osobito se zabranjuje kontakt s monahinjama. Sve tri dijecezanske sinode zabranjuju bilo kakav odnos s njima (bilo da se radi o posjećivanju samostana ili preko bilo kakvih drugih pismenih ili usmenih pošiljki), osim najbliže rodbine (roditelja, braće i sestara). Svećenicima se isto

66 Usp. J. Grisar, Die Reform der „Reservatio casuum“ unter Papst Clemens VIII., 383.

67 Johannes Dominicus MANSI, Sacrorum conciliorum nova et amplissima collectio, 36/2: synodi occidentales 1569 - 1609, Paris, 1901. (pretisak Florentiae, 1961.), 45.

68 Sinoda je 1598. godine donijela odluku O konkubinatu kako crkvenjaka (klerika) tako i laika (De concubinatu tum ecclesiasticorum tum laicorum). D. FARlati, Illyricum sacrum, V, 150; A. Marani, Atti pastorali di Minuccio Minucci, 79 - 80; J. VRandeČić, Zadarski nadbiskup Minuccio Minucci i njegova jadranska misija, 202; Z. STRIKA, Zadarska dijecezanska sinoda, 49. Poligamija nije, poslije Tridentskog sabora, u „kršćanskoj Europi“ bila dokinuta, nego je dugo prakticirana, kako to pokazuje Michael Borgolte, Kulturelle Einheit und religiöse Differenz. Zur Verbreitung der Polygamie im mittelalterlichen Europa, Zeitschrift für historische Forschung, 31, Berlin, 2004., 1 - 36. 
tako zabranjuje slavljenje misa u redovničkim crkvama bez dozvole ordinarija. Zabrane su očigledno proizašle iz praktičnih razloga, a izgleda da se svašta zbivalo iza samostanskih zidina jer su se zadarske dijecezanske sinode često osvrtale na redovnički život u ženskim samostanima. ${ }^{69}$

Posebno se ističe odredba broj jedanaest sa sinode 1598. godine kojom se rezervira slučaj ubojstva bračnog partnera: zabrana se očigledno odnosila na oba spola, ubojstva supruge bila su daleko češća negoli obratno. Kasnije sinode (1663. i 1680. godine) ne spominju više taj slučaj. Uz njih se zabranjuje seksualni odnos $s$ javnim bludnicima i osobito zabrana da se pored zakonite supruge dovede $u$ obitelj još jedna, druga žena (priležnica) koja bi rađala djecu. Je li ta odredba imala odjeka u praksi ili nije teško je, bez dugotrajnog proučavanja dostupnih vrela, nešto detaljnije napisati, svakako je bilo pojedinih slučajeva sve do sredine 20. stoljeća.

Četvrta grupa su zabrane koje se odnose na uzurpaciju materijalnih sredstva koja se nalaze u rukama Crkve. Dijecezanska sinoda iz 1598. godine rezervirala je uskraćivanje desetine mjesnom biskupu (br. 23). ${ }^{70}$ Ta odredba proizlazi iz opće gospodarske krize tijekom druge polovice 16. stoljeća na zadarskom području. Situacija se nije promijenila ni tijekom 17. stoljeća. Obje kasnije sinode (1663. i 1680. godine) ukazuju na tu činjenicu (br. 14), a uz njih još strogo zabranjuju zauzimanje crkvene imovine koja je rezervirana rednim brojem 18 .

Peta grupa su rezervirani slučajevi savjesti usmjerenih protiv prekršaja koje su počinili klerici ili prekršaji učinjeni protiv klerika. Oni se, nasuprot sinoda u drugim europskim zemljama, samo sporadično spominju. Njima se pribraja broj dvanaest sa sinode 1598., gdje se rezervira mjesnom biskupu slučaj da netko nekog klerika istuče ili da se sramotno i neprimjerno o njemu izražava. To znači da se dobar glas klera ne smije bezrazložno kaljati. Kasnije dvije sinode (1663. i 1680. godine) u popisu rezerviranih slučajeva savjesti ne spominju više takvu mogućnost, te su one na taj način slijedile odluku Rimske kurije da se umanje rezervirani slučajevi.

69 Tako sinoda 1598. godine donosi odredbu $O$ monabinjama (De monialibus). D. FARLATI, Illyricum sacrum, V, 151 - 153; A. MARANI, Atti pastorali di Minuccio Minucci, 84 - 90; J. VRANDEČIĆ, Zadarski nadbiskup Minuccio Minucci i njegova jadranska misija, 204; Z. STRIKA, Zadarska dijecezanska sinoda, 53 - 54. Zadarska dijecezanska sinoda koju je 1647. godine sazvao nadbiskup Bernard Florio (1642. - 1656.) isto tako je donijela odluku O monabinjama (De monialibus). Z. STRIKA, Sinoda zadarske crkve, 59.

70 Uz to, sinoda je donijela zaključak $O$ uzurpaciji (uzurpatorima ili prisvojiteljima) crkvenih dobara (De usurpantibus bona ecclesiastica). D. FARlati, Illyricum sacrum, V, 150; A. Marani, Atti pastorali di Minuccio Minucci, 81 - 82; J. VRANDEČIĆ, Zadarski nadbiskup Minuccio Minucci $i$ njegova jadranska misija, 203; Z. STRIKA, Zadarska dijecezanska sinoda, 49 - 50. 
Sinoda 1598. godine zabranjuje kleru sudjelovanje na igrama, a istodobno im se zabranjuje noću biti naoružanima, zatim noćno skitanje i pjevanje ljubavnih pjesma te sudjelovanje u bilo kakvim predstavama (br. 25 i 26). Dijecezanske sinode 1663. i 1680. godine ne spominju više tu zabranu, ali to ne znači da je zadarskom kleru bilo dozvoljeno noćno lutanje i noćno sastajanje. Već je dijecezanska sinoda koju je 1566. godine sazvao nadbiskup Mucije Callini odredila u kanonu 33 da zadarski klerici ne smiju noću hodati po gradu, osim ako je to iz pastoralnih razloga prijeko potrebno. U tom slučaju, mogu to činiti samo u svećeničkoj odjeći sa svjetiljkom u ruci. ${ }^{71}$ Pokrajinski sabor koji je sazvao biskup veronski i apostolski pohoditelj Agostino Valier (1531. - 1606.), a koji je započeo sa zasjedanjima dan ili dva prije 20. svibnja 1579. godine u benediktinskom samostanu sv. Krševana, zabranjuje svim klericima u Dalmaciji kockanje i kartanje, sudjelovanje u raznim profanim igrama (zabavljanje i plesanje u kolu), noćnim zabavama i noćno pjevanje pjesama koje su često imale ljubavni karakter. ${ }^{72}$

Očigledno često obnavljanje zabrana pokazuje konkretnu situaciju u Zadarskoj nadbiskupiji: klerici nisu baš previše marili za mnogobrojne propise koje su donosili nadbiskupi ili njihovi najbliži suradnici. Oni su, na svoj vlastiti način, živjeli zajedno s vjernicima, često su bili prisiljeni raditi iste poslove kao i oni te su se tako i u svakodnevnom životu ponašali. Oni su, pored svih vremenskih i prostornih razlika, na svoj vlastiti način postali preteče „svećenika djelatnika“ koji su se pojavljivali u Francuskoj kratko vrijeme prije Drugog Vatikanskog koncila i svojim radom ukazivali na neophodno prilagođavanje kršćanskih struktura konkretnim vremenskim i prostornim prilikama.

\section{ZAKLJUČAK}

U sklopu proučavanja rezerviranih slučajeva (de casibus reservatis), odluke zadarskih dijecezanskih sinoda o pridržanim slučajevima skladno se uklapaju u opću sinodalnu praksu svršetkom 16. i tijekom 17. stoljeća. Njihov je broj varirao, dok je sinoda 1598. godina još obznanila 28 rezerviranih slučajeva savjesti, dotle su ih druge dvije sinode ponešto umanjile. To se zbilo po utjecajem

71 Usp. HR-Državni arhiv u Zadru, Fasc. Miscellanea II, br. 1, fol. 16; Z. STRIKA, Sinoda zadarske crkve, 58, bilj. 46; Z. STRIKA, Die Diözesansynoden, 283.

72 D. FARlATI, Illyricum sacrum, V, 135 - 136; Ivan Vitezić, La prima visita apostolica posttridentina in Dalmazia (nell' anno 1579) [excerpti, ex dissertatione ad lauream], Romae, 1957., 42 - 43; V. BlAžEvić, Crkveni partikularni sabori, 106. 
Rimske kurije koja je poticala biskupe neka umanje broj rezerviranih slučajeva. Zadarski nadbiskupi Teodor Balbi i Ivan Evanđelist Parzaghi slijedili su naputke Kongregacije za biskupe i redovnike, ali ipak nisu bili u tome dosljedni. Oni su jednim dijelom umanjivali broj rezerviranih slučajeva, tako da su povezivali više rezerviranih slučajeva zajedno navodeći ih pod jednim te istim brojem. $\mathrm{Na}$ taj način umanjivali su njihov redni broj, ali stvarni broj rezerviranih slučajeva ostao je isti.

Poslije dijecezanske sinode koja je zasjedala 1663. godine prevedeni su rezervirani slučajevi na hrvatski jezik kako bi mogli biti dostupni i onim svećenicima koji nisu dovoljno poznavali latinski jezik. Njihov prijepis koji je danas dostupan u Arhivu Hrvatske akademije pokazuje da je tekst bio rasprostranjen i da su se njime svećenici služili. 


\section{IZVORI I LITERATURA}

\section{IZVORI:}

Znanstvena knjižnica u Zadru, Synodus Prima Illustrissimi ac Reverendissimi Domini Theodri Balbi Miseratione Divina Archiepiscopi Iadrensis, 1663., Ms 843.

Arhiv Zadarske Nadbiskupije (HR-AZDN) - 16/6, Prva biskupska sinoda (Synodus dioecesana prima).

\section{LITERATURA:}

Benvenuti de, Angelo, Storia di Zara dal 1409 al 1797, Milano, 1944.

Bianchi, Carlo Federico, Zara Cristiana, sv. I, Zara, 1877.

Bianchi, Carlo Federico, Fasti di Zara religioso-politico-civile dell anno 1184 av. Cr. Sino all'anno 1888 dell'era volgare, Zara, 1888.

BLAžEvić, Velimir, Concilia et synodi in territorio hodiernae Jugoslaviae celebrata, Vicetiae, 1967.

BLAŽEvić, Velimir, Crkveni partikularni sabori i dijecezanske sinode na području Hrvatske i drugih južnoslavenskih zemalja, Croatica Christiana Fontes, 27, Zagreb, 2012.

Bogović, Mile, Katolička Crkva i pravoslavlje u Dalmaciji za mletačke vladavine, Analecta Croatica Christiana, 14, drugo izdanje, Zagreb, 1993.

Borgolte, Michael, Kulturelle Einheit und religiöse Differenz. Zur Verbreitung der Polygamie im mittelalterlichen Europa, Zeitschrift für historische Forschung, 31, Berlin, 2004., 1 - 36.

Cikojević, Ante, Stara reservacija i novi dekret „Cum experientia”, Bogoslovska Smotra, 8, Zagreb, 1917., 224-245, 329 - 349.

Collectanea in usum Secretariae S. Congregationis Episcoporum et Regularium, cura di Andrea Bizzarri, Roma, 1863.

Conciliorum Oecumenicorum Decreta, curantibus Giuseppe Alberigo, Josepho A. Dossetti, Pericles-P. Joannou, Claudio Leonardi, Paulo Prodi, consultante Hubertus Jedin, edidit Istituto per le Scienze Religiose, treće izdanje, Bologna, 1973., njemački prijevod sv. III: Konzilien der Neuzeit, priredio Josef Wohlmuth, Paderborn-München-Wien-Zürich, 2002.

Conciliorum Oecumenicorum Generaliumque Decreta, sv. III: The Oecumenical Councils of the Roman Catholic Church from Trient to Vatican II (1545-1965), prir. Klaus Ganzer, Giuseppe Alberigo, Alberto Melloni, Turnhout, 2010. 
Constitutiones et Decreta Illustrissimi ac Reverendissimi Domini Domini Evangelistae Parzaghi Miseratione Divina Archiepiscopi Iadrensis, In sua prima dioecesana synodo promulgatae die 13. 14. et 15. mensis Octobris 1680., HRArhiv Zadarske nadbiskupije - 16/6, Biskupska sinoda (Synodus dioecesana) za nadbiskupa E. Parzaghi.

Corpus iuris canonici, II, prir. Aemilius Friedberg, Lipsiae, 1879. (pretisak Graz, 1959.).

ČorAlić, Lovorka, Jedan neobjavljeni dokument o suživotu na mletačkoturskoj granici u zadarskom području u XVII. stoljeću, Historijski Zbornik, 45, Zagreb, 1992., 213 - 218.

Lovorka Čoralić, Prilozi životopisu zadarskoga nadbiskupa Teodora Balbija (1656. - 1669.), Croatica Christiana Periodica, 20, Zagreb, 1996., 83 - 91.

Čoralı́́, Lovorka, Prilog životopisu zadarskog nadbiskupa Ivana Evanđelista Parzaghija (1669. - 1688.), Croatica Christiana Periodica, 31, Zagreb, 2007., $57-66$.

Demel, Sabine, Handbuch Kirchenrecht. Grundbegriffe für Studium und Praxis, 2. durchgesehene und aktualisierte Auflage, Freiburg, 2013.

FARLATI, Daniele, Illyricum sacrum, V, Venetiis, 1775.

Franov-Živković, Grozdana, Glagoljske moralno-kazuističke odredbe ninskih biskupa, 17. i 18. st., RZHAZd, 57, Zagreb-Zadar, 2015., 185 - 216.

Gaudemet, Jean, Le Gouvernement de l'Eglise à l'époque classique. IIe Partie: Le gouvernement local, Paris, 1979.

Gliubich, Simone, Dizionario biografico degli uomini illustri della Dalmazia, Vienna-Zara, 1856. (pretisak Bologna, 1974.).

GrISAR, Joseph, Die Reform der „Reservatio casuum“ unter Papst Clemens VIII., Saggi storici intorno al papato dei Professori della Facoltà Storia ecclesiastica, Miscellanea Historiae Pontificiae, 21, Roma, 1959., 305 - 385.

Hefele, Carl Joseph von, Conciliengeschichte: nach den Quellen bearbeitet, sv. V, zweite vermehrte und verbesserte Auflage besorgt von Alois Knöpfler, Freiburg i.Br., 1886.

Hefele, Carl Joseph von, Leclerce, Henri, Histoire des conciles d'après les documents originaux, V, Paris, 1912. (pretisak 1973.).

Hinschius, Paul, Das Kirchenrecht der Katholiken und Protestanten in Deutschland. System des katholischen Kirchenrechts mit besonderer Rücksicht auf Deutschland, vol. III, Berlin, 1883. (pretisak Graz, 1959.).

Klein, Jürgen, John Wickliffe und die Verweltlichung des Katholizismus im spätmittelalterlichen England, Zeitschrift für Religions-und Geistesgeschichte, 39, Leiden, 1987., 226 - 252. 
Kolanović, Josip, Zadarska nadbiskupija prema izvještajima ad limina 15991799., Sedamnaest stoljeća Zadarske crkve, 1, 379 - 413.

Koller, Alexander, Minuccio Minucci (1551-1604). Ein Diplomat in päpstlichen und bayerischen Diensten, Bayerische Römer - römische Bayern. Lebensgeschichten aus Vor- und Frühmoderne, prir. Rainald Becker, Dieter J. Weiß, St. Ottilien, 2016., 249 - 274.

LoNČAR, Pavao, Podmetnuće kao reservat i poslije novoga Kodeksa, Bogoslovska Smotra, 11, Zagreb, 1923., 316 - 329.

MANSI, Johannes Dominicus, Sacrorum conciliorum nova et amplissima collectio, 21: ab anno 1109 ad annum 1166 inclusive, Paris, 1901 (pretisak Florentiae, 1961.).

MANSI, Johannes Dominicus, Sacrorum conciliorum nova et amplissima collectio, 36/2: synodi occidentales 1569 - 1609, Paris, 1901. (pretisak Florentiae, 1961.).

Marani, Alberto, Atti pastorali di Minuccio Minucci, arcivescovo di Zara (15961604), Roma, 1970.

MiLČETIĆ, Ivan, Hrvatska glagoljska bibliografija, Starine JAZU, 33, Zagreb, 1911. Modrić, Oliver, Kol Anović, Josip, Vodič arhiva Zadarske nadbiskupije, Zadar, 2013.

Müller, Wolfgang P., Die Abtreibung. Anfänge der Kriminalisierung 1140-1650, Köln-Weinar-Wien, 2000.

Neumann, Friederike, Öffentliche Sünder in der Kirche des späten Mittelalters. Verfahren, Sanktionen, Rituale, Köln-Weinar-Wien, 2008.

Prodi, Paolo, Eine Geschichte der Gerechtigkeit. Vom Recht Gottes zum modernen Rechtsstaat. Aus dem Italienischen von Annette Seemann, zweite Auflage, München, 2005.

Raukar, Tomislav, Petricioli, Ivo, Švelec, Franjo, Peričić, Šime, Zadar pod mletačkom upravom 1409-1997, Prošlost Zadra - knjiga III, Zadar, 1987.

Ruzza di, Vincenzo, Minuccio Minucci di Serravalle e la sua famiglia, I Minucci. Arcivescovi, letterati e Cavalieri di Malta. Atti del Convegno Internazionale 6 maggio 2000. Collegio San Giuseppe di Vittorio Veneto, prir. Mario Ulliana, Venezia, 2000., 25 - 59.

Schmitz, Heribert, Die Konsultationsorgane des Diözesanbischofs, Handbuch des katholischen Kirchenrechts, dritte, vollständig neubearbeitete Auflage, prir. Stephan Haering, Wilhelm Rees, Heribert Schmitz, Regensburg, 2015., $620-637$.

Sedamnaest stoljeća Zadarske crkve. Zbornik radova sa znanstvenog skupa o 1700. godišnjici mučenišstva sv. Stošije (Anastazije), Zadar, 16.-18. studenog 2004., 
sv. 1: Od ranokršćanskog razdoblja do pada Mletačke Republike, uredio Livio Marijan, Zadar, 2009.

Strika, Zvjezdan, Zadarske sinode u svjetlu povijesnih vrela, Sedamnaest stoljeća Zadarske crkve, Zbornik radova sa znanstvenog skupa o 1700. godišnjici mučeništva sv. Stošije (Anastazije), Zadar, 16.-18. studenog 2004., sv. 1: Od ranokršćanskog razdoblja do pada Mletačke Republike, uredio Livio Marijan, Zadar, 2009., 45 - 104.

STRIKA, Zvjezdan, „Catalogus episcoporum et archiepiscoporum urbis Iadertinae" arhiđakona Valerija Pontea, $R Z H A Z d$, 48, Zagreb-Zadar, 2006., $81-185$.

STRIKA, Zvjezdan, Pokušaj suzbijanja glagoljice na Zadarskoj sinodi 1460. godine, Croatica Christiana Periodica, 34, Zagreb, 2010., 29 - 38.

Strika, Zvjezdan, Die Diözesansynoden von Zadar unter Erzbischof Muzio Callini mit der Edition der synodalen Beschlüsse aus dem Jahre 1566, Begegnung der Kirche in Ost und West im Spiegel der synodalen Strukturen. Festschrift für Petar Vrankić zum 70. Geburtstag, prir. Johannes Grohe, Gregor Wurst, Zvjezdan Strika, Hermann Fischer, St. Ottilien, 2017., 237 - 291.

Strika, Zvjezdan, Zadarska dijecezanska sinoda 1598. godine, Croatica Christiana Periodica, 43, Zagreb, 2019., 41 - 57.

STRIKa, Zvjezdan, Sinoda zadarske crkve 1647. godine, Croatica Christina Periodica, 29, Zagreb, 2005., 43 - 60.

ŠKalabrin, Nikola, Crkvena zajednica i strukture suodgovornosti, Bogoslovska smotra, 69, Zagreb, 1997., 461 - 472.

ŠT EFAnIĆ, Vjekoslav, Glagoljski rukopisi Jugoslavenske akademije, I dio, Zagreb, 1969.

ŠTiGLIĆ, Martin, Katoličko pastirsko bogoslovje, I-II, Zagreb, 1886. - 1887.

VitezIĆ, Ivan, La prima visita apostolica posttridentina in Dalmazia (nell' anno 1579) [excerpti, ex dissertatione ad lauream], Romae, 1957.

VRandečIć, Josip, Zadarski nadbiskup Minuccio Minucci i njegova jadranska misija, Zagreb, 2017.

Wiegand, Peter, Diözesansynoden und bischöfliche Statutengesetztgebung im Bistum Kammin. Zur Entwicklung des partikularen Kirchenrechts im spätmittelalterlichen Deutschland, Forschungen zur Pommerischen Geschichte, 32, Köln-Weimar-Wien, 1988.

Wiтsch, Norbert, Synodalität auf Ebene der Diözese. Die Bestimmungen des universalkirchlichen Rechts der Lateinischen Kirche, Kirchen- und Staatskirchenrecht, 1, Paderborn-München-Wien-Zürich, 2004. 
Zvjezdan STRIKA

\section{DECISIONS OF ZADAR DIOCESAN SYNODS ON RESERVED \\ CASES (DE CASIBUS RESERVATIS) IN THE CONTEXT OF COUNCIL THOUGHT}

\section{SUMMARY}

As part of the penitential practice, reserved cases of conscience developed late in church practice, only when penance with extremely harsh punishments had disappeared from the church practice. Their introduction was to more effectively anticipate the danger of a moral decline as harsh sentences were lacking. Their application, therefore, did not mean condemning the crimes committed even more severely or passing draconian judgments. Still, the aim was to prevent more successfully such or similar offences in the future. They were first reserved to the pope, and when the great difficulties of their more effective implementation were realized, they passed over to the local bishop. The decisions of the three diocesan synods of Zadar from 1598, 1663 and 1680 harmoniously fitted into the general synodal practice in the early 16 th and 17 th century. Their number varied from one synod to another, while the synod convened after his visitation by Archbishop Minucius de Minucci announced 28 reserved cases of conscience in 1598. At the same time, the other two synods reduced them. The Zadar archbishops, Teodor Balbi and Ivan E. Parzaghi followed the instructions of the Congregation for Bishops and Monks, which sought to mitigate reserved cases of conscience. They partially reduced the number of reserved instances, so that they connected several of them, listing them under the same name. In that way, they only reduced their ordinal number, but in fact, the actual number of reserved cases remained the same.

The Synodal Conclusion of 1598 was published by Daniel Farlati, and based on a new transcript kept today at the German Historical Institute in Rome, Alberto Marani once again published it. The acts of the other two diocesan synods have remained in manuscript to this day. The paper publishes for the first time a synodal conclusion from the synod of 1663 and the one from 1680 . The Synod in 1680 took over the text from the previous synod, and it differs slightly in content and only in a few places. After the diocesan synod (1663), the provisions on reserved cases were translated into Croatian so that they could also be made available to those priests who did not know Latin well enough. Their transcript is today kept in the archives of the Croatian Academy of Sciences and Arts in Zagreb and was published by Grozdana Franov-Živković.

Keywords: reserved cases, Zadar diocesan synods, decisions of the synod, Zadar, Zadar church, early modern age. 